\title{
ISLAM AND CULTURAL PLURALITY OF INDONESIA
}

\author{
Moh. Masduki \\ IAI Sunan Giri Ponorogo \\ Email:masdukigtg82@gmail.com
}

\begin{abstract}
Abstrak
Tulisan ini membahas tentang wacana Islam Nusantara yang mengemuka pada tahun-tahun terakhir ini, masuknya Islam ke Nusantara dihadapkan kepada wajah nusantara yang samasekeali berbeda dengan tempat labir dan tumbubnya Islam yakni jazirah Arab, Islam Indonesia dihadapkan dengan wajah Nusantara yang multikultur dan plural, sebagian besar masyarakat Indonesia ingin mengamalkan ajaran Islam tetapi enggan untuk meninggalkan budayanya, hal tersebut menjadikan dialog dan bubungan saling memberi dan menerima antara ajaran Islam dan budaya lokal. Berbagai pemikiran berupaya merumuskan cara bagaimana Islam dapat beradaptasi dengan budaya local dengan tanpa meninggalkan ketaubidan dan ajaran ushuliyab lainya. Amin Abdullah menyampaikan bahwa diperlukan sebuah fresh ijtibad untuk mengahadapi hal kontemporer, tidak akan cukup hanya dengan mengulang-ulang pengalaman masa lalu tanpa melibat perkembangan setempat. Said Aqil Siradj menjadikan metode tawazun, i'tidal dan tawasuth dalam rangka mencari titik temu dari keragaman tersebut. Sementara Abd. Muqsith Gozali menawarkan metode mashlahah mursalah, istibsan dan 'urf agar ajaran Islam dapat berpadu dengan budaya Nusantara. Dari hasil interaksi Islam dan budaya Nusantara menghasilkean sebuah peradaban Islam Nusantara yang unik misalnya gaya berpenampilan muslim Nusantara, arsitektur bangunan tempat ibadah Nusantara, bentuk budaya interaksi antar umat beragama sperti Siwalima di Maluku dan Maluku Utara, perpaduan bahasa memunculkan aksara jawi atau pegon. Pluralitas dan keragaman adalah suatu bal yang harus disikapi dengan cara dan metode yang tepat bukan malah dibindari dan menjaubkan diri. Kemanan untuk berinteraksi antara Agama dan Budaya akan menghasilkan sebuah peradaban bibrida yaitu peradaban Islam Nusantara.
\end{abstract}

Kata kunci; Peradaban, Islam, pluralitas, keragaman budaya Nusantara

\section{Pendahuluan}

Dalam dunia akademis wacana "Islam Nusantara" bisa jadi bukan hal yang baru, istilah ini kembali mengemuka dan menjadi "trending topic" di masyarakat Indonesia pada tahun 2015. Dalam pembukaan acara Istighotsah menyambut Ramadhan dan pembukaan munas alim ulama NU, Minggu (14/06/2015) di
Masjid Istiqlal ketua PBNU Said Aqil Siradj menegaskan bahwa NU akan terus memperjuangkan dan mengawal model Islam Nusantara, dalam acara yang sama presiden RI Joko Widodo pun mengamini dan menyatakan mendukung model "Islam Nusantara", (BBC. Indonesia;15 Juni 2015). Dari sini-lah sitilah Islam Nusantara kemudian mengemuka di masyarakat Indonesia, istilah yang pada 
mulanya akrab di mata akademisi ini kemudian memunculkan beberapa penilaian masyarakat muslim Indonesia, setidaknya adalah sebagai berikut:

1) Islam Nusantara menjadi istilah yang dimunculkan dan bahkan mungkin dimiliki oleh salah satu ormas terbesar di Indonesia yaitu Nahdlatul Ulama $(\mathrm{NU})$,

2) Islam Nusantara dianggap sebagai sebuah (aliran) Islam baru yang patut untuk disesatkan. Seperti halnya Ananda Puja Wandra yang menguraikan tulisannya dengan judul "Konsep Islam Nusantara, Kesesatan yang Menyesatkan, dalam tulisannya Puja Wandra menganalisis kesesatan Islam Nusantara dari segi frasa maupun makna, penulis mengungkapkan bahwa penggunaan istilah Islam Nusantara mempersempit makna kata Islam, dari segi konsepnya pun Puja Wandra menilai bahwa Islam Nusantara tidak satupun berdasar pada Al-Qur'an dan Hadits. (Ananda Puja Wandra, Konsep Islam Nusantara, Kesesatan yang Menyesatkan, Kompasiana;3 Agustus 2015).

Sampai saat ini kajian terhadap Islam Nusantara masih terus berlangsung, hal ini sebagai bentuk upaya untuk menjelaskan Islam Nusantara kepada masyarakat muslim bahwasannya gagasan ini mempunyai pijakan yang kuat dan bukanlah sebuah aliran baru dalam Islam yang sesat atau bahkan menyesatkan, beberapa kajian mutakhir terkait dengan Islam Nusantara misalnya tulisan Ahmad Baso dengan judul "Ilmu Ekonomi Pesantren dan Islam Nusantara" kajian ini mengkaji dan menjelaskan bagaimana hakikat substansi ekonomi Nusantara (Ahmad Baso, Jurnal Tashwirul Afkar, Vol. 35, 2016).

Akhmad Khoirul Fata dalam tulisannya menjelakan bahwasanya kemunculan istilah Islam Nusantara adalah atas respon atas Islam Trans-nasional di mana sebenarnya yang terjadi adalah perebutan simpati masyarakat oleh gerakan Isam mainstream (santri lama) dengan gerakan Islam baru (santri baru).

Khoirul Fata juga menjelaskan bahwasannya dua wajah gerakan Islam ini sudah ada sejak masa penjajahan di Indonesia, ia juga cenderung tidak sepakat dengan istilah Islam Trans-nasional yang menjadi "lawan" Islam Nusantara dikarenakan keduanya merupakan sama sama bersumber dari timur tengah atau dengan kata lain kedua-duanya sama-sama bisa disebut sebagai Islam Trans-nasional. (A. Khoirul Fata, M Nur Ikhwan, 2017)

Mark Woodward menjelaskan juga wacana ini dengan mengutip pendapat Hodgson (1975) dalam tulisannya Pergulatan tentang wacana Islam Nusantara akan mudah terselesaikan jika wacana Islam Nusantara dilihat bukan sebagai Islam itu sendiri akan tetapi dilihat sebagai sebuah peradaban Islam. Sebagai sebuah peradaban wacana Islam 
Nusantara adalah warna atau ekspresi muslim Indonesia dalam menjalankan syariah Islam meliputi sastra, pertunjukan, tradisi, sains, filsafat, arsitektur monumental dan ekspresi muslim Indonesia lainnya. (Mark Woodward, 2017)

Lebih lanjut Mark Woodward menjelaskan tentang keberadaan Islam Nusantara, menurutnya Islam Nusantara adalah simbologi yang diciptakan oleh ulama NU dan akademisi terkemuka yang menggabungkan aspek-aspek Islam Sunni tradisional, termasuk Sufisme Jawa dan pada tingkat yang jauh lebih rendah dari budaya Indonesia lainnya dalam upaya eksplisit untuk melawan upaya SalafiWahhabi untuk mengubah Islam dan budaya Indonesia termasuk juga gerakan ekstremis yang keras yaitu ISIS. (Mark Woodward, 2017)

Terlepas dari polemik wacana Islam Nusantara dan Islam Transnasional, menurut penulis hal ini serupa dengan permulaan dikajinya Islam sebagai sebuah ilmu (Islamic studies) di mana pada saat itu para pengkaji Islam mempunyai latar belakang yang beragam ketika mengkaji Islam mulai dari keinginan melanggengkan kekuasaan, menghancurkan Islam dan murni mengkaji Islam atas dasar latar belakang keilmuan. Dalam kajian ini penulis lebih mengkaji wacana Islam Nusantara dari sisi keilmuan dan mengkaji tentang bagaimana seharusnya Islam menampilkan dirinya di Indonesia ketika dihadapkan dengan kenyataan social serta keunikan budaya Nusantara.

\section{Dialog Islam dan Budaya Nusantara}

Meminjam istilah Komarudin Hidayat Islam adalah ajaran universal dalam wadah local, kalimat singkat ini menjelaskan bahwasannya ketika Islam hadir ia membawa ajaran universal sebagaimana diungkapkan dalam al-Qur'an "bahwasannya Rasulullah diutus untuk membawa ajaran rahmatan lil 'alamin", akan tetapi ajaran Islam turun dan tumbuh di wilayah local yaitu jazirah Arab, padahal siapapun orangnya ia akan tumbuh dalam asuhan budaya dan tradisi orang tuanya dan lingkungan yang bersifat local. (Komarudin Hidayat, 2012;150). Artinya pada saat itu Islam turun bukan dalam ruang yang kosong tanpa agama atau tanpa budaya, tentunya ajaran Islam pada saat itu akan berdialog dengan budaya tempat ia tumbuh.

Letak geografis yang keras masyarakat Arab pun berwatak keras dan mudah untuk mengangkat pedang merebut atau mempertahankan sumber air atau padang tempat menggembala ternak, maka tidak heran ketika Islam muncul mendapat perlawanan sengit dari masyarakat Arab sendiri Nabi pun terpaksa ber hijrah untuk menghindari ancaman-ancaman terhadap umat muslim yang masih minoritas saat itu, Ungkapan tentang budaya Arab yang keras tidak menganggap bahwasannya semua budaya Arab tidak baik, tentunya terdapat budaya dan kebiasaan-kebiasaan 
yang lain yang baik dan ketika Islam datang budaya baik itu tidak perlu ditentang oleh Islam, hal ini berlaku juga ketika Islam datang di Nusantara dengan keunikan budayanya.

Dari awal masuknya Islam ke wilayah nusantara memang mempunyai keunikan tersendiri dibandingkan dengan wilayah sekitar Timur Tengah misalnya, wilayah Indonesia yang terpisah jauh dari wilayah Arab secara mengejutkan menjadi kantong umat Muslim terbesar dengan tanpa diwarnai peperangan, padahal tidak terbantahkan bahwasannya Nusantara sempat menjadi pusat agama HinduBudhha dengan bukti peninggalan artefakartefak besar yang dapat ditemukan diseluruh penjuru Nusantara.

Proses Islamisasi Nusantara yang demikian tersebut menurut pendapat para sejarawan dipengaruhi oleh berbagai hal; menurut salah satu pendapat Islam masuk Indonesia dibawa oleh para pedagang muslim Gujarat, sifat pedagang ini dinilai menjadi pengaruh penyebaran Islam di Indonesia berjalan damai, para pedagang tidak mungkin memakai kekerasan hal ini justru malah dapat merugikan dirinya. (Komarudin Hidayat: 2012) Pendapat lain menjelaskan bahwa Islam yang dikembangkan di Indonesia lebih banyak bermuatan tasawuf sehingga lebih dapat terbuka dengan cenderung mengesampingkan sisi eksoterik, memang pada abad ke-16 perkembangan Islam di Nusantara diwarnai dengan pemikiran tasawuf, warna ini tampak dari bagaimana para ulama Nusantara mengembangkan pemikiran tasawuf seperti Hamzah Fanshuri dan muridnya Syamsudin alSumatrani atau di wilayah jawa dikembangkan oleh Syeh Siti Jenar dengan wihdatul wujud nya.

Mneurut Khamami Zada, (2014) dalam perkembangannya ajaran Syamsudin alSumatrani ini didebat oleh Nurudin Arraniri karena ajarannya dianggap bertabrakan dengan syariah. (Shihab, 2001; 50) Dalam catatan sejarah memang tidak ditemukan bahwa masuknya Islam ke wilayah Nusantara menggunakan cara kekerasan atau perang, tentu hal itulah yang kemudian berpengaruh sampai sekarang bahwa mayoritas Islam di Indonesia bersifat inklusif, ramah dan gerakannya lebih bersifat cultural bukannya gerakan structural.

Dalam konteks Indonesia Islam tumbuh dalam setting social yang plural dan multikultur dengan letak geografis kepulauan dan keadaan tanah yang subur gemah ripah lob jinawi, setting tumbuh kembang Islam di Indonesia jelas berbeda dengan Arab dengan budaya padang pasirnya. Keragaman dan pluralitas di Indonesia tentu tidak bisa ditolak atau dihindari, hal tersebut sudah menjadi sunnatullah dan harus disikapi dengan terbuka bukannya eksklusif dan menutup diri dan memandang orang lain adalah ancaman, orang lain seharusnya dipandang sebagai mitra dalam membangun peradaban terlebih dalam era global sekarang ini, tidak ada seseorang atau 
sebuah komunitas yang dapat mencukupi kebutuhannya sendiri dan siapapun yang tidak siap untuk menjalin kemitraan dengan orang lain yang berbeda bangsa, suku dan agama pada akhirnya akan merusak sebuah peradaban bukan malah membangunnya. Mengahadapi keadaan yang plural yang dibutuhkan bukan bagaimana menjauhkan diri dari pluralitas melainkan bagaimana mencari cara atau mekanisme untuk menyikapi pluralitas tersebut. (Ghozali, 2009; 3)

Atas dasar tersebut para cerdik cendekia ber-ijtihad dalam rangka mencari cara atau mekanisme menyikapi wilayah Nusantara yang plural, Amin Abdullah misalnya mengemukakan bahwa keilmuan agama Islam memerlukan fresh ijtihad untuk menghadapi kehidupan kontenporer, tidak cukup mengulang ulang pengalaman masa lalu tanpa melihat bagaimana perkembanagn masa kini dan masa depan (Abdullah, 2015; 66).

Menanggapi pluralitas Amin Abdullah juga menekankan diperlukannya dialog dalam kalam modern, yang titik tekannya tidak mencari kemenangan kelompok atau mazhab, keyakinan atau organisasi keagamaan tertentu, melainkan dialog untuk mencari kebenaran universal memiliki tujuan, antara lain: Untuk saling mengenal, Untuk saling mengerti, Untuk saling mengasihi, Untuk membangun solidaritas, Untuk hidup bersama secara damai.
Metode yang diyakini telah memberikan warna khas dan unik dalam ekspresi keislaman di Nusantara yang berbeda dengan Islam di Timur Tengah (Arab).adalah tawâzun,i'tidâl, tawasuth serta selalu berupaya mencari konvergensi dan titik temu di antara berbagai mazhab pemikiran dan aliran keagamaan.(Siroj, 148-149)

Mekanisme dan cara Islam di Indonesia berpadu dengan budaya nusantara bergerak dalam wilayah agama yang ijtihadiyah hal inilah yang mendasari bahwa pemikiran ini bukanlah sesuatu yang menyeleweng dari tuntunan pokok atau ushul dalam Islam. Hal ini dilakukan agar ajaran Islam bisa diamalkan dan diresapi dengan baik dengan keunikan Indonesia. Muqshid Ghozali metode yang ditonjolkan adalah maslabah mursalah, istibsan, dan 'urf. (Ghazali, 2015;106.)

Salah satu penerapan maslabah mursalah di Indonesia adalah diterimanya konsep Pancasila oleh para ulama yang turut andil merumuskan proses kemerdekaan Indonesia, Pancasila dianggap tidak bertentangan dengan Al-qur'an maupun al-hadis dan dapat mempertahankan persatuan dan keutuhan masyarakat Indonesia yang multikultur. (Ghazali, 2015; 107)

Dalam penggunaan istihsan Muqsith Ghozali mencontohkan penggunaan busana muslimah Indonesia, muslimah nusantara menggunakan kaim sampir dan kerudung dengan kain bawah yang tidak 
sampai menutup betis seutuhnya, hal ini dianggap boleh dengan metode istibsan bilurf atau mengambil hal baik dari sebuah tradisi masyarakat. (Ghazali, 2015; 107)

Al-'urf juga diterapkan ulama nusantara dengan tujuan muslim Nusantara dapat ber-Islam dengan tanpa meninggalkan budayanya, hal ini tampak pada bangunan arsitektur masjid nusantara yang berbeda dengan Timur Tengah dengan kubahkubahnya yang besar. (Ghazali, 2015; 107).

Selain beberapa hasil dari mekanisme dan cara Islam di Indonesia berinteraksi dengan budaya nusantara yang diungkapkan Muqisth Ghozali tersebut masih banyak lagi yang dapat terlihat wujud budaya dan peradaban Islam Indonesia hingga saat ini misalnya arsitektur masjid Demak, Ranggo atau atap yang berlapis pada masjid tersebut diambilkan dari konsep Meru' dari masa pra-Islam (Hindu dan Budha) yang terdiri dari Sembilan susun. Sunan Kalijaga memotongnya menjadi tiga susun saja, melambangkan tiga tahap keberagaman seorang (Wahid, 2015:34), bentuk masjid semisal masjid Demak ini banyak ditemui pada masjid-masjid lain khusunya di pulau Jawa.

Arsitektur masjid Nusantara ini sama halnya dengan arsitekur masjid di wilayah Timur Tengah dengan menara-menaranya yang menjulang tinggi, nama menara ini diambilkan dari bahasa yang berbau syirik, yaitu berasal dari tradisi Yunani kuno dan agama majusi sebagai tempat untuk memperembahkan api suci sebagai bentuk pemujaan kepada dewa. Kata menara berasal dari manarah yang berarti tempat api yang kemudian diadopsi ke dalam bahasa Indonesia menjadi menara (Komarudin Hidayat, 2010; 52) Hal serupa juga bisa kita lihat bangunan masjid Kudus yang mirip dengan bangunan rumah Ibadah agama Hindhu.

Di Indonesia juga telah lama terjadi bahwa pembagian waris antara suami istri mendapatkan masukan berupa model yang berasal dari adat, yitu adat perpantangan di Banjarmasin dan gono gini di Yogya-Solo yang pada perkembangannya juga menyebar di Jawa Timur. Sedangkan dalam kaitannya dengan pernikahan misalnya, sebenarnya rukun bagi sahnya hubungan suami istri sangat sedikit, yaitu ijab, qabul, saksi, dan wali. Sedang selebihnya diserahkan kepada adat, misalnya tentang pelaksanaan upacara peresmiannya. Di sini adat berperan sebagai penghubung pola-pola perilaku baru dengan tetap berpijak kepada aturan normatif dari agama (Abdurrahman Wahid, dalam Islam Nusantara, 2015:36).

Misalnya lagi nabi tidak pernah menetapkan beras sebagai benda zakat, melainkan gandum. Lalu ulama mendefinisikan gandum sebagai qut albalad, makanan pokok. Dan karena definisi itulah gandum berubah menjadi beras untuk Indonesia (Abdurrahman Wahid, dalam Islam Nusantara 2015:38). 
Budaya memang hasil dari sebuah proses mengambil dan memberi, dalam hal tampilan seorang muslim pun demikan, bagaiamana mereka memakai warna dan corak baju, tutup kepala yang dipakai, gaya rambut baik kumis maupun janggut, dikur atau tidak dicukur, kesemuanya tersebut adalah sebuah proses mengambil dan memberi dari berbagai budaya, seperti halnya beberapa decade terakhir ini marak dipakai symbol yang dianggap "Islami" seperti jidat yang menghitam, janggut yang panjang, celana setengah betis bagai laki-laki dan mamakai burqa bagi perempuan sehingga mata saja yang tampak, praktek semacam ini membuat mereka berbeda dengan kebanyakan muslim Indonesia lainnya.

Sebagain besar muslim Indonesia tidak memanjangkan janggut dan mereka memakai tutup kepala berwarna hitam bernama peci atau songkok, hanya beberapa saja para ulama yang memakai penutup kepala berupa surban atau memakai jubah sebagaimana pakain Timur Tengah. Maka jelas dari kebanyakan umat Islam disini tidak mau untuk menyingkirkan penampilan pribumi. Preferensi singkat mereka Potongan Eropa (batik kamisol, mantel), baju Asia Selatan (sarung,peci) dan Cina (baju koko) (Machasin, 2017;211)

Sebagaian besar muslim Indonesia mentaati ajaran agama untuk menutup aurat dengan tanpa meninggalkan identitas penampilan mereka, mereka tidak mau menjadi orang Arab, Iran, atau
Afghanistan saat mereka masuk Islam, hal demikian inilah yang kemudian menjadi salah satu tanda penting identitas muslim di Nusantara. (Horstmann, Alexander, 2009:45-47; Hasan, Noorhaidi, 2009: 121 140).

Dalam penggunaan bahasa pun muslim Nusantara juga memiliki identitas dengan perpaduan antara bahasa Jawa, Melayu, dan Arab, maka tersebutlah dengan aksara jawi atau dikenal dengan aksara pegon di wilayah jawa.

Dengan karakter yang khas ini Islam di Nusantara mebentuk ranah budaya tersendiri dalam dunia Islam. Dijelaskan oleh Azzumardi Azra bahwa setidaknya da delapan wajah peradaban Islam di dunia yaitu: Persia-Iran, Turki, anak benua India, Nusantara, Cina atau Asia Timur, Afrika Sudan/Afrika Hitam/Sub-Sahara, dan belahan dunia Barat. (Azra, 1994, )

Agama dan tradisi local sepanjang sejarah perjalanannya memang berbaur dengan proses saling memberidan menerima, agama besar akan melahirkan peradaban besar sementara budaya yang sudah mapan tidak mudah untuk digeser oleh agama. Meski pada mulanya agama diyakini datang dari langit ketika berkembang di bumi agama mesti menggunakan kendaraan, sarana dan symbol budaya yang tumbuh di bumi manusia. Maka agama dan budaya pada urutannya akan menyatu dan kemudia melahirkan tradisi baru yang merupakan 
campuran antara tradisi local dan agama. (Hidayat, 2016:253)

Terkait dengan wilayah Indoensia yang plural dengan enam agama tumbuh di sana maka Islam seharusnya juga menampilkan diri dengan wajah yang ramah dan mudah diterima, dalam al-Qur'an pun dijelaskan bahwasannya keragaman agama tersebut dijadikan oleh Allah supaya terjadi kompetisi dalam hal kebajikan (QS. Albaqarah; 148). Karena kita tahu bahwa tidak sedikit umat Islam yang memposisikan umat non muslim sebagai "musuh" atau pihak "kafir" yang harus diperangi Mereka seolah-olah ingin menjadikan semua umat manusia dalam satu wadah yang sama, padahal ini adalah sebuah cita-cita yang justru bertentangan dengan kehendak Allah (QS. Al-Maidah; 48)

Banyak umat Islam yang memaknai pesan agama secara dangkal, Al-qu'an yang kaya akan pesan-pesan universal non sektarian telah disimplifikasi sehingga yang muncul adalah pesan-pesan ekstrimisme dan ajaran komunal, eksklusif serta truth claim, padahal dengan pembacaan yang mendalam banyak ayat al-Qur'an yang mengatur metode dan cara pergaulan dan berkomunikasi dengan umat lain.

Salah satu komunikasi unik antar umat beragama di Nusantara dapat kita lihat di Maluku dengan nama budaya Siwalima, Siwalima adalah hubungan antar pemeluk agama untuk saling tolong menolong antar umat beragama, misalnya tolong menolong dalam membangun dan merenovasi rumah ibadah. Sebagain dari muslim radikal menentang hal ini, argument mereka adalah hadis Nabi yang berbunyi 'Man a'ana 'ala ma.'siyat in walaw bi-syatr kalimat "in kāna syarik an labüfi-ba". (Machasin, ;209).

Maka dari itu diperlukan pembacaan yang mendalam terhadp teks-teks agama diiringi dengan ijtihad yang segar, hal demikian tidak akan menjadikan beragama dan keragaman sebagai pemicu kecemburuan dan aksi kekerasan yang justru akan mengancam keutuhan Nasional sebagai rumah bersama serta justru akan menghambat lahirnya sebuah peradaban besar yaitu peradaban Islam Nusantara.

\section{Penutup}

Wacana tentang Islam Nusantara yang mengemuka bukan bermaksud untuk meremehkan Islam melainkan ingin menunjukkan bahwa sebuah peradaban besar akan lahir dengan sikap umat Islam yang inklusif dan apresiatif terhadap budaya luar tanpa kehilangan ushuliyahnya, sejarah membuktikan bahwa peradaban besar Islam lahir dari sikap inklusif misalnya Iran, Turki, atau masa keemasan pada dinasti Abasiyah. Jika sikap inklusif tanpa sinkretis ini bisa ditunjukkan muslim Indonesia sebagai umat mayoritas maka bukan tidak mungkin sebuah peradaban besar Islam akan lahir dari Nusantara, dan sebaliknya jika yang tumbuh adalah sikap eksklusif dan tidak 
dapat menghargai budaya local maka yang terjadi adalah pemiskinan budaya dan peradaban Islam di Nusantara.

\section{DAFTAR PUSTAKA}

Abd. Moqsith Ghozali dalam Buku Islam Nusantara; dari Ushul Fiqib Hingga paham Kebangsaan, Jakarta, Mizan, 2015

Abd. Moqsith Ghozali, Argumen Pluralisme Agama, Depok, Penerbit Kata Kita, 2009

Abdurrahman Wahid, dalam Buku Islam Nusantara; dari Ushul Fiqih Hingga paham Kebangsaan, Jakarta, Mizan, 2015

Ahmad Baso, Ilmu Ekonomi Pesantren dan Islam Nusantara, Jurnal Tashwirul Afkar, Vol. 35, 2016

Ananda Puja Wandra, Konsep Islam Nusantara, Kesesatan yang Menyesatkan, Kompasiana;3 Agustus 2015

Azyumardi Azra, Jaringan ulama: Timur Tengah dan kepulauan Nusantara abad XVII dan XVIII: melacak akar-akar pembaruan pemikiran Islam di Indonesia. Mizan, 1994.

BBC. Indonesia;15 Juni 2015

Hasan, Noorhaidi, Transnational Islam in Indonesia, in Peter Madville (eds) Transnational Islam in South and Southeast Asia, Movements, Networks and Conflict Dynamics, the National Bureau of Asian Research, 2009

Horstmann, Alexander, Transnational Ideologies and Actors at the Level Society in South and Southeast Asia, 2009

Khamami Zada, Wajah Islam Nusantara Abad XVI-XX, Jurnal Tashwirul Afkar Edisi No. 34, 2014

Khoirul Fata, M Nur Ikhwan, Pertarungan Kuasa dalam Wacana Islam Nusantara, Islamica (Jurnal Studi Keislaman) vol. 11, No. 2, Maret 2017).

Komarudin Hidayat, Agama Punya Seribu Nyawa,Jakarta, Noura Books ; 2012 
Komarudin Hidayat, Psikologi Beragama, Jakarta, Mizan Publika ; 2010

M. Amin Abdullah, dalam Buku Islam Nusantara; dari Ushul Fiqib Hingga paham Kebangsaan, Jakarta, Mizan, 2015

Machasin, Transnational Ideologies and Religious Local Wisdom, Journal Heritage of Nusantara, Vol.6 No.2 December 2017

Mark Woodward, Islam Nusantara: A Semantic and Symbolic Analysis, Journal Heritage of Nusantara; Vol 6 No. 2 Des. 2017

Said Aqil Siroj, Rekonstruksi Aswaja Sebagai Etika Sosial, dalam Buku Islam Nusantara; dari Ushul Fiqih Hingga paham Kebangsaan, Jakarta, Mizan, 2015

Shihab, Alwi. Islam sufistik:" Islam pertama" dan pengarubnya bingga kini di Indonesia. Mizan, 2001 